\title{
Santos Medina: Vértigo y Equilibrio
}

Recibido: 20.02.2016 / Aprobado: 25.02.2016

\author{
Por Álvaro Urtecho ${ }^{1}$
}

Cuando los hombres del próximo Oriente, en fechas ya perdidas de la vasta noche de los tiempos, ensayaron por primera vez la escritura cuneiforme, seguramente creyeron que esos trazos oscuros, esos surcos profundos, plasmados sobre la piedra o el barro, iban a durar el justo tiempo, todo el justo tiempo necesario para que otros ojos, muchos ojos, innumerables ojos se detuvieran asombrados, en la incesante liturgia de su desciframiento. Los signos, la escritura persisten, y guardamos efectivamente la memoria en el alma. La memoria, el recuerdo preciso o impreciso de los hechos y los hombres que fueron.

"No existe historia más del alma", dice Saint John Perse, y pareciera verdad la afirmación de ese gran poeta francés cuando pensamos en el espectáculo de la materia que se destruye en sí misma, en la incandescencia de las constelaciones y planetas que aparecen y desaparecen como un fulgor aterrado. Saetas, bólido, magmas, lava, agua quemada, torbellinos desmelenados, astros destazados, el universo en expansión y contracción. ¿Será cierto, pues, que sólo el alma tiene historia? Frente a la exuberante pero putrefacta materia, ¿en que intersticios surge y se acomoda o agazapa el espíritu?, ¿en que reconditeces la voz de la conciencia, la memoria, el trazo, la escritura?, ¿en qué volutas, volúmenes o círculos? El Cronista, el Poeta no cede en su pregunta; ¿Qué quedó de la época, qué quedó de las épocas?...

Estas observaciones circulares, mínimas, impotentes en su indagación radical, me invaden como ráfagas en el momento que decido descifrar, comprender, leer la pintura de Santos Medina. Nicaragüense nacido en 1942, artista de apasionadas raíces, solitario, autodidacta, testigo y protagonista de uno de los periodo más convulsivos de la historia de su país, combatiente sandinista de vida y corazón, recalcitrante en su arte intransferible, Medina sonríe tensamente desde ese rostro endurecido que exhibe señas y cicatrices del torturado.

Sonríe vagamente para explotar de vez en cuando en apagadas carcajadas demoníacas. Piensa en sus cuadros, en sus obras que se han ido de su casa para siempre, pero que están presentes en el desgarramiento de su ámbito espiritual, en el caparazón de su cráneo, obsesionado por las ideas calurosas de su arte que le persigue por la mañana a la noche, de la luz a la sombra, de la sombra a la luz; unas ideas, una fijezas, un vértigo que lo hacen estar mucho tempo trabajando un cuadro, sin importarle horas ni plazos ni fechas de entrega, embebido totalmente en la auscultación de esas voces antiguas que lo hincan, lo postran de rodillas a la espera, como los santos y los místicos, del milagro o la clave o la cifra para resolver-¿definitivamente?-el problema último de la creación: la captación de la imagen que pueda transfigurar y posibilitar la esencia, la búsqueda de los posible en lo imposible, el desentrañamiento del misterio, porque este artista, este Santos Medina, cuyos ojos vidriados parpadean tras breves y resbaladizas gafas sobreasadas, cree en el rigor de la creación sostenida a fondo, llevada al borde de sus limites, a la experiencia de los límites del Ser si es que así pude llamarse al prurito o a la ambición de crear de la nada un mundo, el Mundo. Y Medina cree en ese mundo: los esboza, lo insinúa, lo construye con intensos colores que oscilan del rojo al negro, al oro, con sus densas texturas que atestiguan su fidelidad a la tradición mesoamericana, su condición de hijo de esta tierra nuestra volcánica y encendida. Pero Medina no se contenta con la elaboración de una textura correcta. No. A él no le interesa la perfección formal, aunque su obra le revele como un supuesto. No se queda en lo que podríamos llamar formalismo de la textura (el texturismo, arriesguemos esta expresión), esa manía de los pintores de Praxis que ha redundado, a estas alturas,

1. Poeta nicaragüense, crítico literario y ensayista. 


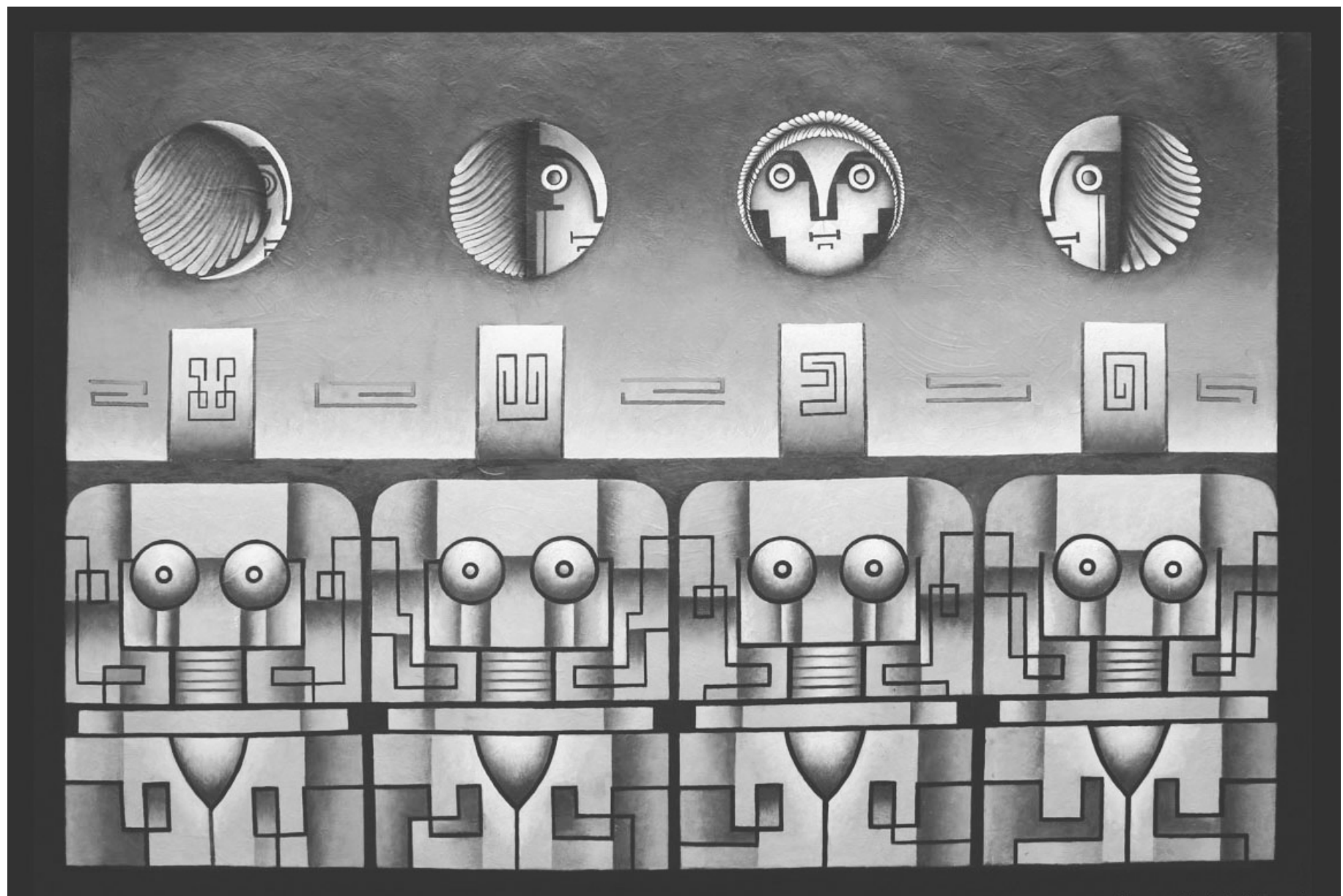

Autor: Santos Medina.

en un estancamiento de las artes plásticas nacionales, en tanto ese formalismo o perfeccionismo de la materia supone una escandalosa ausencia de ideas, una pérdida de la imaginación, una castración o autocercenamiento de la potencia creadora experimental, una negativa a integrar la imagen -las imágenes- en libertad, en progresión y ascensión dialéctica.

Medina apuesta por lo oculto, por lo mágico, por lo otro que habla tenebrosa y luminosamente a los sentidos. No teme: asume su tiniebla, asume los rayos cegadores de la tiniebla y se sumerge en la noche de barro de los tiempos. Su tarea es la de un soñador en vigilia, un soñador que se resiste a aceptar como "realidad" las que nos señalan todos los días los constructores de representaciones "fieles", los dictaminadores del "orden real" agradable a la vista: se trata nada menos que de ordenar las visiones y flujos del caos, percibir el misterio, el ámbito mágico de épocas pasadas para lograr una actualización del mito, un recreación de símbolos y simbolismos - ¿egipcios, sumerios, babilonios, mayas?que se integren a una concepción moderna, surgida de una situación histórica concreta.

"Compactación" (óleo sobre tela 1988), es uno de los cuadros más completos de Medina. Un díptico que representa en sus dos planos, a la pareja humana: un hombre y una mujer que se ofrecen la reconciliación, el abrazo.

Oposición resuelta en unión, superación de la contradicción, fusión del principio masculino con el principio femenino, el Cielo y la Tierra, el Día y la Noche, el Yin y el Yang. Una superposición de pirámides que ascienden con filo de pezones hacia la luna, símbolo de serenidad y unión partida en dos por la raya divisoria del díptico. Un cuadro de cuidadosa gradación compositiva que nos transporta a una dimensión musical, es 


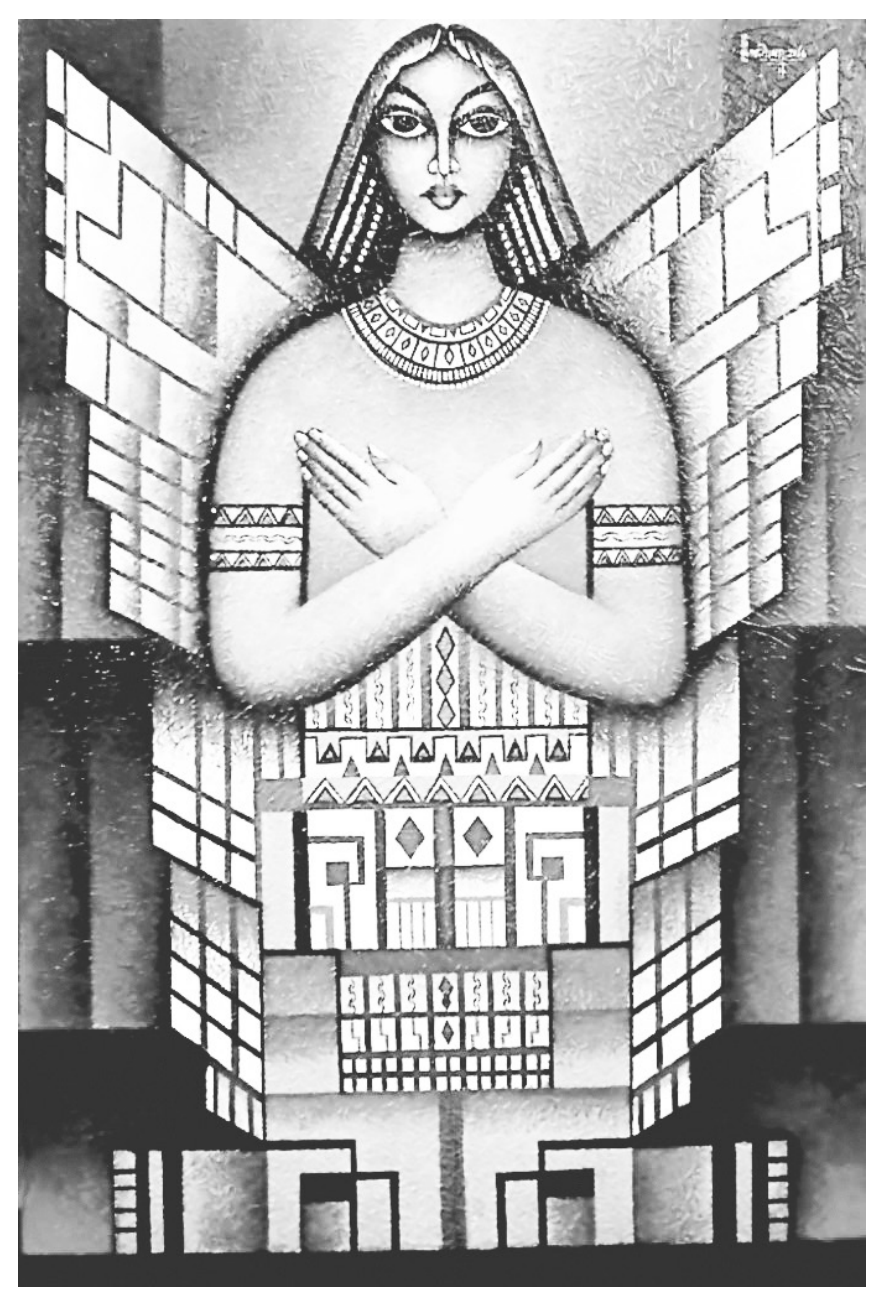

Autor: Santos Medina.

decir, a una concepción eminentemente rítmica de la composición especial. Una música de esferas, por lo suave y tranquila que es, por lo sensual y tersa, por lo graduado y evanescente de su tono nocturno.

Definitivamente Medina es un analista del espacio, que ha estudiado probablemente el geometrismo de Mérida, así como el patrimonio de las estelas y ornamentación mayas prehispánicas. Un artista que analiza las formas para proceder a su descomposición y, a la vez, encontrar en ella el secreto de su unidad: la unidad compacta de la forma, la unidad que integra finalmente todos los elementos desintegrados (fragmentados, aislados) en virtud del método compositivo elegido. En este sentido, es de destacar la rítmica construcción de la anatomía humana a partir de formas tubulares que recuerdan a Léger o a algún otro constructivista que se me escapa.
Es evidente que la visión mágica de Medina es asistida por un equilibrio claramente revelado en la organización racional del espacio y discernible en la proliferación de cuadros, rectángulos, circunferencias, conos, formas piramidales, tal como puede advertirse en Acciones revolucionarios indoamericana (1982) donde la segmentación de la figura humana es múltiple y estratificada: círculos que son cabezas, líneas y surcos que son brazos, estelas que son piernas. Todo plasmado sobre una textura que refleja la materia en bruto la erosión geológica del planeta, la tierra calcinada y horadada, la tierra del cráter y el grito, su superficie rugosa vista desde el alto vuelo. O la técnica de óleo, acrílico y arena sobre madera expuesta en Vigilante Nocturno (1985), obra en la que podemos apreciar una sabia alternancia entre la luz y sombra, entre el ocre intenso de los bordes y el amarillo y oro encendido del centro.

Es reveladora también su obsesión por las figuras espectrales: su visión de los combatientes victoriosos en la "Toma del Bunker" (Óleo sobre madera, 1979), pese a la alegría eufórica que motiva su ejecución, está impregnado por el fulgor de la muerte. Tan cierto que esos muchachos con fusiles y pañoletas rojinegras parecieran surgir súbitamente de una cripta, transfigurados, como en los bajorrelieves funerarios egipcios, por una fina arenilla de ultratumba.

Sí, Santos Medina tiene en su arte un fuerte regusto por tiempos lejanos. Su mirada se pierde en la noche y su deseo es imposible: unir el pasado con el presente, superponer época y mitos, fundir lo clásico con lo indígena, Venus con Xilonem. Su trabajo actual apunta en esa dirección. No se sabe cuál será el resultado. Pero hay que esperar, porque como dice el poeta, "lo importante no es vivir sino viajar". 